\title{
Transactions
}

Cite this: Dalton Trans., 2012, 41, 12839

wWw.rsc.org/dalton

PAPER

\section{Chiral Ag(I) and Pt(II) complexes of ditopic NHC ligands: synthesis, structural and spectroscopic properties $\dagger+$}

\author{
Paul Marshall, ${ }^{a}$ Robert L. Jenkins, ${ }^{a}$ William Clegg ${ }^{b}$ Ross W. Harrington, ${ }^{b}$ Samantha K. Callear, ${ }^{c}$ \\ Simon J. Coles, ${ }^{c}$ Ian A. Fallis ${ }^{a}$ and Athanasia Dervisi ${ }^{*} a$
}

Received 31st July 2012, Accepted 6th September 2012

DOI: $10.1039 / \mathrm{c} 2 \mathrm{dt} 31740 \mathrm{k}$

The butyl and isopropyl derivatives $(\mathbf{4 I}, \mathbf{5 B r})$ of chiral pool derived bis-imidazolium dehydrohexitol salts have been prepared. The ditopic N-heterocyclic carbenes $\mathbf{4}$ and $\mathbf{5}$ form dinuclear $\operatorname{Ag}(\mathrm{I})$ and $\mathrm{Pt}(\mathrm{II})$ complexes. All compounds were fully characterised by multinuclear NMR spectroscopy. The bisimidazolium salt 4I and platinum complexes cis- $\left[\mathrm{Pt}_{2}(\mu-\mathbf{2})\left(\mathrm{dmso}_{2} \mathrm{Cl}_{4}\right]\right.$ and $c i s$ - $\left[\mathrm{Pt}_{2}(\mu-\mathbf{4})\left(\mathrm{dmso}_{2} \mathrm{Cl}_{4}\right]\right.$ were characterised by X-ray crystallography. In the case of the $\mathrm{Pt}(\mathrm{II})$ complexes, the carbene ring is positioned in a sterically preferred orientation, approximately perpendicular to the platinum coordination plane. The ${ }^{1} \mathrm{H},{ }^{13} \mathrm{C},{ }^{15} \mathrm{~N}$ and ${ }^{195} \mathrm{Pt}$ NMR spectra of the platinum complexes show the presence of rotamers due to hindered rotation about the carbene-metal bond.

\section{Introduction}

N-Heterocyclic carbene (NHC) ligands and their transition metal complexes have established themselves as a cornerstone of modern coordination chemistry and are now used in a wide range of applications. Platinum(II)-NHC complexes in particular catalyse a number of important reactions, such as hydrosilylations, ${ }^{1}$ hydroaminations, ${ }^{2}$ tandem hydroboration-cross-coupling reactions ${ }^{3}$ and diboration of unsaturated molecules. ${ }^{4}$ Platinum(II)NHC complexes have also seen recent activity in medicinal applications as possible chemotherapeutic agents. ${ }^{5}$ Thus efficient syntheses of platinum-NHC complexes are of considerable current interest. Synthetic routes to Pt-NHC complexes include direct reaction of the carbene precursor in the presence of base, ${ }^{1 e, 6}$ or of the free carbene, with suitable platinum salts. ${ }^{7}$ Alternatively, transmetalation of $\mathrm{Ag}-\mathrm{NHC}$ complexes with a platinum source is also known. ${ }^{8}$

Silver(I) carbenes are extensively used as ligand transfer agents for the majority of imidazolium and other azolium salts,

${ }^{a}$ School of Chemistry, Cardiff University, Main Building, Park Place, Cardiff, CF10 3AT, UK. E-mail: dervisia@cardiff.ac.uk;

Fax: +44 (0) 29 20874030; Tel: + 44 (0) 2920874081

${ }^{b}$ School of Chemistry, Newcastle University, Newcastle upon Tyne NE1

7RU,UK.E-mail: bill.clegg@newcastle.ac.uk;

Tel: +44 (0) 1912226649

${ }^{c}$ School of Chemistry, University of Southampton, Highfield, Southampton,SO171BJ, UK.E-mail: s.j.coles@soton.ac.uk;

Fax: +44 (0) 2380596 723; Tel: +44 (0) 2380596722

$\dagger$ Dedicated to Professor David Cole-Hamilton on the occasion of his retirement and for his outstanding contribution to transition metal catalysis.

† Electronic supplementary information (ESI) available: X-ray crystallographic data as CIF files for the compounds 4I, 8 and 9; figures showing NMR spectra. CCDC 893546-893548. For ESI and crystallographic data in CIF or other electronic format see DOI: $10.1039 / \mathrm{c} 2 \mathrm{dt} 31740 \mathrm{k}$ forming a part of a convenient, and sometimes the only, route for the synthesis of metal carbene complexes. ${ }^{9} \mathrm{Ag}(\mathrm{I})-\mathrm{NHC}$ complexes have also found many medicinal applications, mainly due to their activity as antimicrobials. ${ }^{10}$ Other potential uses include high-end materials applications, such as luminescent chemosensors. ${ }^{11}$ Silver-carbene complexes are structurally diverse, displaying a broad range of coordination motifs, ranging from simple two-coordinate linear molecules ${ }^{9 e, 12}$ to helicates, ${ }^{13}$ polymers, ${ }^{14}$ rings,${ }^{15}$ cages ${ }^{16}$ and clusters. ${ }^{17}$

Based on our previously reported chiral pool derived dehydrohexitol framework precursor $\mathbf{1},{ }^{18}$ we recently described an efficient method leading to the bis-carbene precursor imidazolium salts $2 \mathbf{X}$ (Scheme 1) with 2,5-exo stereochemistry. ${ }^{19}$ The endo and exo stereochemistry refers to the substitution with respect to the bent V-shaped core of the fused dehydrohexitol ring. Here we report the synthesis of the isopropyl- and butylimidazole derivatives ( $\mathbf{4 X}$ and $\mathbf{5 X}$ ) following an alternative synthetic route and expand on the coordination chemistry for this family of bridging NHC ligands, to include examples of their Pt(II) complexes.

\section{Discussion}

The 2,5-exo-bisimidazole 3 was prepared from the reaction of ditosylate 1 with imidazole in $\mathrm{dmf}$ in the presence of $\mathrm{Cs}_{2} \mathrm{CO}_{3}$ (Scheme 1). Subsequent quaternerisation with the corresponding alkyl halide afforded the bis-isopropyl- and butyl-imidazolium salts $4 \mathrm{I}$ and $\mathbf{5 B r}$. Following counterion metathesis with potassium hexafluorophosphate in water, $\mathbf{4} \mathbf{P F}_{\mathbf{6}}$ is furnished as a crystalline white solid and $\mathbf{5} \mathbf{P F}_{\mathbf{6}}$ as a colourless viscous ionic liquid. The imidazolium salts have the expected exo stereochemistry at the 2 and 5 positions of the bicyclic ring as in the parent hexitol, L-iditol. The dicationic salts are readily soluble in water and 

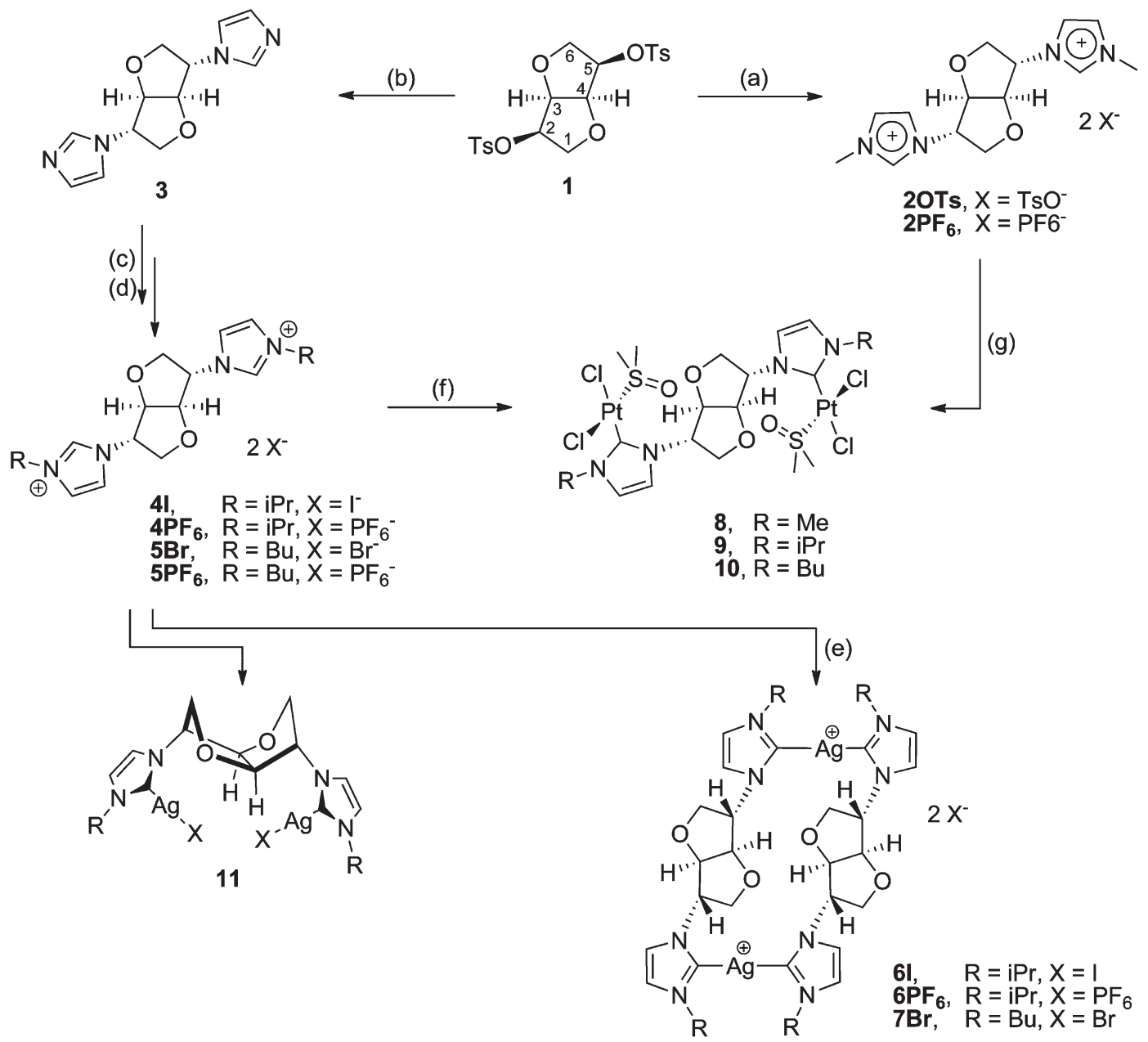

Scheme 1 Reagents and conditions. (a) $\mathrm{N}$-Methylimidazole, $140{ }^{\circ} \mathrm{C}$; (b) $\mathrm{Cs}_{2} \mathrm{CO}_{3}$, dmf, $100{ }^{\circ} \mathrm{C}$; (c) 4I: excess isopropylbromide, $\mathrm{CH}_{3} \mathrm{CN}$, reflux, 5Br: excess butylbromide, dmf, $100{ }^{\circ} \mathrm{C}$; (d) excess $\mathrm{KPF}_{6}, \mathrm{H}_{2} \mathrm{O}$; (e) $\mathrm{Ag}_{2} \mathrm{O}, \mathrm{CH}_{2} \mathrm{Cl}_{2}$, room temperature, 2 days; (f/g) $\mathrm{K}_{2} \mathrm{PtCl}{ }_{4}$ or $\mathrm{PtCl}_{2}, \mathrm{NaOAc}$ dmso, $70{ }^{\circ} \mathrm{C}, 2$ days.

polar organic solvents such as lower alcohols, acetone, acetonitrile and dmso. Single crystals of $\mathbf{4 I}$ suitable for X-ray studies were grown from an acetonitrile solution of the salt, and the structure of the cation is shown in Fig. 1.

\section{Silver(I) complexes}

The silver(I) complexes of carbenes $\mathbf{4}$ and $\mathbf{5}$ were prepared from the reaction of $\mathrm{Ag}_{2} \mathrm{O}$ with the corresponding imidazolium salts, 4I, $4 \mathbf{P F}_{\mathbf{6}}$ and $\mathbf{5 B r}$. NHC carbenes $\mathbf{4}$ and $\mathbf{5}$ form the bridged metallacyclic dinuclear silver complexes, $\left[\mathrm{Ag}_{2}(\mu-\mathrm{NHC})_{2}\right][\mathrm{X}]_{2}$ shown in Scheme 1, irrespective of the metal to ligand ratio and type of counterion used. The analogous methyl-imidazolyl complex $\left[\mathrm{Ag}_{2}(\mu-2)_{2}\right]\left[\mathrm{PF}_{6}\right]_{2}$ and its solid-state structure has been reported previously by us. ${ }^{19}$ Unfortunately, the isopropyl and butyl derivatives, $\mathbf{6} \mathbf{I}$ and $\mathbf{7} \mathbf{B r}$, did not afford good crystals of sufficient quality to allow for their X-ray structure determinations. As was the case for NHC ligand 2, the neutral acyclic bis-monocarbene complexes (11) were not observed. Electrospray mass spectra show maximal mass peaks at $m / z 1001$ and 1009 for the silver metallacycle complexes, $\mathbf{6 I}$ and $\mathbf{7} \mathbf{B r}$ respectively, corresponding to loss of one of the counterions from the

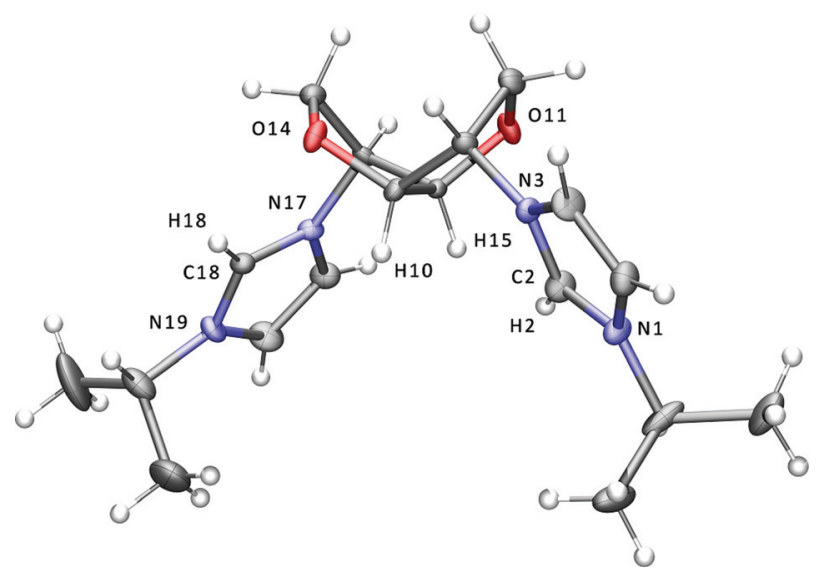

Fig. 1 Displacement ellipsoid plot at the $50 \%$ probability level of the bis-imidazolium cation of $\mathbf{4 I}$. The iodide anions are omitted for clarity. Selected bond lengths $(\AA)$ and angles $\left({ }^{\circ}\right)$ : N1-C2 1.333(5), C2-N3 1.341(5), N17-C18 1.331(5), C18-N19 1.329(5), N1-C2-N3 109.3(4), N17-C18-N19 109.5(3).

parent compound, $[\mathrm{Ag}(\mu-\mathrm{NHC})]_{2}[\mathrm{X}]_{2}$. In the ${ }^{13} \mathrm{C}$ NMR spectra of the silver complexes the carbene resonance appears as a sharp 
singlet at $\delta 180.6 \mathrm{ppm}$ for $\mathbf{6 I}$ and $\delta 181.6 \mathrm{ppm}$ for $\mathbf{7 B r}$. Coupling to ${ }^{107} \mathrm{Ag}$ or ${ }^{109} \mathrm{Ag}$ was unobserved in both cases. Silver-carbene complexes have been used previously in transmetalation reactions with platinum(II) salts to afford the corresponding $\mathrm{Pt}(\mathrm{NHC})$ complexes. $^{8 b, 20}$ In the case of the silver complex $7 \mathbf{B r}$ reaction with $\mathrm{Pt}(\operatorname{cod}) \mathrm{Cl}_{2}$ afforded mixtures of $\mathrm{Pt}(\mathrm{II})$-containing species and partially protonated carbene ligand.

\section{Platinum(II) complexes}

In order to avoid time- and resource-consuming routes, the platinum complexes 8-10 were prepared directly from the reaction of the corresponding ligand salts $\left(\mathbf{2} \mathbf{P F}_{\mathbf{6}}, \mathbf{4} \mathbf{P F}_{\mathbf{6}}\right.$ and $\left.\mathbf{5} \mathbf{P F}_{\mathbf{6}}\right)$ with $\mathrm{PtCl}_{2}$ or $\mathrm{K}_{2} \mathrm{PtCl}_{4}$ in quantitative yields (Scheme 1). Reactions were carried out in the presence of NaOAc in dmso, under aerobic conditions using unpurified technical grade solvent. Reactions in other solvents, e.g. dma ( $N, N^{\prime}$-dimethylacetamide), afforded complex mixtures of intractable products. The above synthetic procedure afforded the bis-monocarbene complexes, cis- $\left[\mathrm{Pt}_{2}(\mu-\mathrm{NHC})(\mathrm{dmso})_{2} \mathrm{Cl}_{4}\right]$, regardless of the metal to ligand

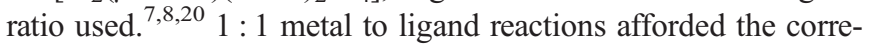
sponding $c i s-\left[\mathrm{Pt}_{2}(\mu-\mathrm{NHC})(\mathrm{dmso})_{2} \mathrm{Cl}_{4}\right]$ complexes, with the excess imidazolium salt remaining unreacted. Complexes 8-10 are air- and moisture-stable and can be stored for prolonged times in air without any visible decomposition. They are soluble in chlorinated solvents, acetonitrile and dmso.

\section{Solution NMR measurements}

Relatively small changes are observed in the ${ }^{1} \mathrm{H}$ NMR spectra for the hydrogen atoms of the proligands of $\mathbf{2 , 4}$ and $\mathbf{5}$ upon coordination to silver(I). More pronounced deshielding of the proton resonances, however, is seen for the platinum complexes, most likely due to the divalent metal. Notably, there are large downfield shifts of the methine protons $\left(\mathrm{H}^{2 / 5}\right)$ adjacent to the imidazolyl nitrogen atoms from $c a$. $\delta 5.1 \mathrm{ppm}\left(\mathrm{CD}_{3} \mathrm{CN}\right)$ in the imidazolium salts to $\delta 5.9-6.1 \mathrm{ppm}\left(\mathrm{CD}_{3} \mathrm{CN}\right)$ in the coordinated ligands. A large downfield shift is also observed for the isopropyl methine proton of 9 , from $\delta 4.73 \mathrm{ppm}$ in 4 I to $5.63 \mathrm{ppm}$ $\left(\mathrm{CD}_{3} \mathrm{CN}\right)$.

\section{Restricted rotation about the $\mathrm{C}-\mathrm{Pt}$ bond}

The ${ }^{1} \mathrm{H}$ and ${ }^{13} \mathrm{C}$ NMR spectra of the platinum complexes, 8-10, reveal more than one isomers present in solution which have been attributed to rotamers arising from restricted rotation about the $\mathrm{Pt}-\mathrm{C}_{\mathrm{NHC}}$ bond. High metal-carbene rotation barriers $(>92 \mathrm{~kJ}$ $\mathrm{mol}^{-1}$ ) have been observed for $\mathrm{Rh}(\mathrm{I})$ - and $\mathrm{Ir}(\mathrm{I})-\mathrm{NHC}$ systems and attributed mainly to steric effects. ${ }^{21}$ Similarly, for Pt(NHC) (dmso) $\mathrm{Cl}_{2}$-type complexes Rourke et al. have reported barriers to rotation in excess of $85 \mathrm{~kJ} \mathrm{~mol}^{-1}$. $8 a$
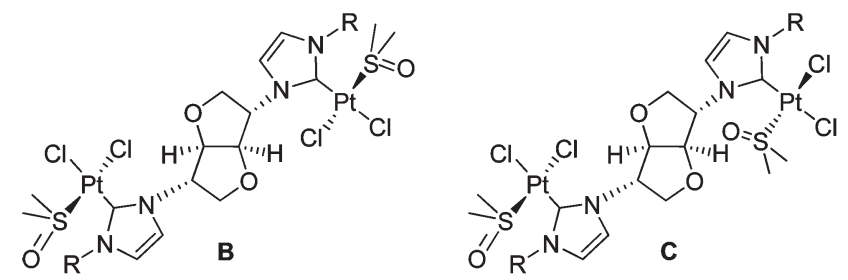

In the case of the dinuclear complexes, 8-10, there are three possible rotamers arising from slow rotation about the $\mathrm{Pt}-\mathrm{C}_{\mathrm{NHC}}$ bond; two of $C_{2}$ symmetry with the dmso ligands either in (isomer A, Scheme 1) or out (isomer B) with respect to the dehydrohexitol core, and one of $C_{1}$ symmetry with in and out dmso ligands (isomer $C$ ). All three rotamers of 8-10 were observed in different ratios, although due to the complexity of the overlapping signals, these rotamers could not be individually assigned. One common feature in the spectra of the complexes, supporting the existence of three isomers in solution, is the appearance of four distinct doublets for one of the imidazolyl proton resonances, with one doublet for each of the $C_{2}$ symmetric isomers and two doublets for the $C_{1}$ symmetric isomer. In addition, the two methyl groups of the coordinated dmso are diastereotopically inequivalent, as of course are the methyls on the isopropyl group of 9. In an attempt to simplify the ${ }^{1} \mathrm{H}$ NMR spectra, a dmso- $\mathrm{d}_{6}$ solution of complex 8 was heated to $100{ }^{\circ} \mathrm{C}$. However, no significant changes in the chemical shifts were observed, leading us to conclude that a high barrier to rotation about the $\mathrm{Pt}-\mathrm{C}_{\mathrm{NHC}}$ bond also exists for these complexes.

In the ${ }^{195} \mathrm{Pt}$ NMR spectra of complexes 8-10 two signals were observed in each case, centred at $\mathrm{ca}$. $-3500 \mathrm{ppm}$ (referenced to $\left.\mathrm{Na}_{2} \mathrm{PtCl}_{6}\right){ }^{22}$ Presumably, some of the rotamer signals remain unresolved in the corresponding ${ }^{195} \mathrm{Pt}$ NMR spectra. For comparison, the $\delta^{195 \mathrm{Pt}}$ reported for the related carbene complexes, $\left[\mathrm{Pt}(\mathrm{NHC})(\mathrm{dmso}) \mathrm{Me}_{2}\right]$, are in the region of -3900 to $-4000 \mathrm{ppm}^{20}$ The effect of the different $\mathrm{N}$-imidazole substituents $(\mathrm{Me}, \mathrm{iPr}, \mathrm{Bu})$ of complexes 8-10 on the ${ }^{195} \mathrm{Pt}$ NMR chemical shifts $\left(\delta^{195 \mathrm{Pt}}\right)$ is negligible. This is in agreement with reports for other $\mathrm{PtCl}_{2}$ systems, such as those of chelating dipyridyl ligands. ${ }^{23}$ Due to solubility limitations, different solvents were used for each complex during these measurements (dmso-d $\mathrm{d}_{6}$ for $\mathbf{8}, \mathrm{CD}_{3} \mathrm{CN}$ for 9 and $\mathrm{CD}_{2} \mathrm{Cl}_{2}$ for $\mathbf{1 0}$ ). Contrary to previous observations, where large $\Delta \delta^{195 \mathrm{Pt}}$ of $c a .400 \mathrm{ppm}$ were observed with changes in the solvent from $\mathrm{CD}_{2} \mathrm{Cl}_{2}$ to $d m s o-\mathrm{d}_{6}$, there were no significant solvent effects observed for complexes 8-10. ${ }^{24}$

${ }^{1} \mathrm{H}-{ }^{15} \mathrm{~N}$ HMBC spectra were also collected for the platinum complexes. In most cases analyses of the cross-peaks in the twodimensional spectra provided a means of differentiating and assigning the two non-symmetrically substituted imidazolyl ${ }^{15} \mathrm{~N}$ resonances. Relatively small differences in the chemical shifts of the imidazole derived nitrogens were observed $\left(\Delta \delta^{15 \mathrm{~N}}\right)$, with the largest $\Delta \delta^{15 \mathrm{~N}}$ observed for complex 9 at $16 \mathrm{ppm}$ and the smallest for complex 10. In this case, the two ${ }^{15} \mathrm{~N}$ resonances centred at 204.5 ppm remained unresolved. Although the signals for $\mathrm{N}^{\mathrm{O}}$ and $\mathrm{N}^{\mathrm{R}}$ in the ${ }^{15} \mathrm{~N}$ dimension of the spectra for $\mathbf{8 - 1 0}$ were not resolved further, the presence of rotamers is implied after inspection of the cross-section of the peaks in the 2D-spectra (where $\mathrm{N}^{\mathrm{O}}$ represents the nitrogen atom next to the oxolane ring and $\mathrm{N}^{\mathrm{R}}$ the one next to the corresponding alkyl substituent).

Solid state structures of the Pt(II) complexes. The solid-state structures of platinum complexes $\mathbf{8}$ and $\mathbf{9}$ were determined by synchrotron X-ray crystallography. Complexes $\mathbf{8}$ and $\mathbf{9}$ adopt the same $C_{2}$ symmetric spatial arrangement shown in Fig. 2, with complex 9 containing a true $C_{2}$ crystallographic axis. The two platinum centres are trans to each other, facing away from the 

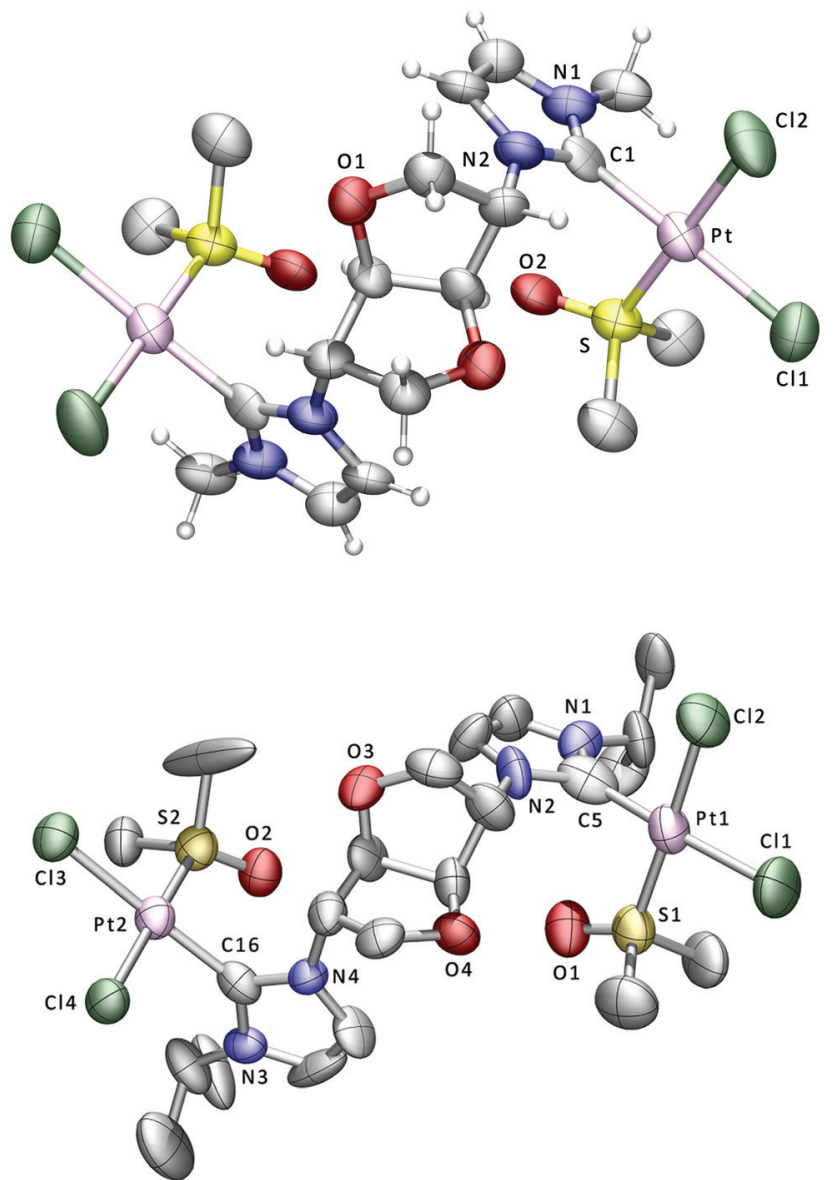

Fig. 2 Displacement ellipsoid plots at the $50 \%$ probability level of the platinum complexes 8 (above) and 9; for clarity only some of the $\mathrm{H}$ atoms are shown. Selected bond lengths $(\AA)$ and angles $\left(^{\circ}\right)$ for 8: Pt$\mathrm{Cl}(1)$ 2.361(8), Pt-Cl(2) 2.305(8), Pt-S 2.205(7), Pt-C(1) 1.98(2), $\mathrm{Cl}(1)-\mathrm{Pt}-\mathrm{Cl}(2)$ 90.0(3), Cl(1)-Pt-S 90.4(3), Cl(1)-Pt-C(1) 176.1(8), Cl(2)-Pt-S 178.9(3), Cl(2)-Pt-C(1) 88.4(6), S-Pt-C(1) 91.2(6). Selected bond lengths $(\AA)$ and angles $\left(^{\circ}\right)$ for 9: $\mathrm{Pt}(1)-\mathrm{Cl}(1)$ 2.335(4), $\mathrm{Pt}(1)-\mathrm{Cl}(2)$ 2.328(4), $\quad \mathrm{Pt}(1)-\mathrm{S}(1) \quad 2.189(4), \quad \mathrm{Pt}(1)-\mathrm{C}(5)$ 1.948(14), $\quad \mathrm{Pt}(2)-\mathrm{Cl}(3)$ 2.338(4), $\mathrm{Pt}(2)-\mathrm{Cl}(4)$ 2.306(4), $\mathrm{Pt}(2)-\mathrm{S}(2)$ 2.190(4), $\mathrm{Pt}(2)-\mathrm{C}(16) 1.88(2)$, $\mathrm{Cl}(1)-\mathrm{Pt}(1)-\mathrm{Cl}(2)$ 90.86(13), $\mathrm{Cl}(1)-\mathrm{Pt}(1)-\mathrm{S}(1)$ 90.88(14), Cl(1)-Pt(1)$\mathrm{C}(5)$ 177.1(4), Cl(2)-Pt(1)-S(1) 175.60(14), Cl(2)-Pt(1)-C(5) 88.3(4), $\mathrm{S}(1)-\mathrm{Pt}(1)-\mathrm{C}(5)$ 90.2(4), Cl(3)-Pt(2)-Cl(4) 90.62(18), Cl(3)-Pt(2)-S(2) 91.02(18), $\quad \mathrm{Cl}(3)-\mathrm{Pt}(2)-\mathrm{C}(16) \quad 176.0(5), \quad \mathrm{Cl}(4)-\mathrm{Pt}(2)-\mathrm{S}(2) \quad 178.04(16)$, $\mathrm{Cl}(4)-\mathrm{Pt}(2)-\mathrm{C}(16)$ 88.3(5), S(2)-Pt(2)-C(16) 90.1(5).

dehydrohexitol core and the dmso ligands assume a syn arrangement facing towards the core (isomer A, vide supra). This more crowded conformation may be stabilised by non-classical $\mathrm{C}-\mathrm{H}$... O hydrogen bonding interactions between the dmso oxygen and bridgehead hydrogen atoms of the dioxolane unit; for complex 9 the relevant $\mathrm{O} \cdots \mathrm{H}$ distances are 2.54 and $2.46 \AA$, and for 8, $2.47 \AA$ (two distances equal by symmetry). ${ }^{25}$ The $\mathrm{Pt}-\mathrm{C}_{\mathrm{NHC}}$ bonds are in the range 1.88(2)-1.98(2) $\AA$, at the lower end of the range reported for other Pt-NHC-dmso complexes. ${ }^{7,8}$ The carbene ring is placed in a sterically preferred orientation, approximately perpendicular to the platinum coordination plane in each case; the corresponding dihedral angles between the imidazole and coordination planes are $81.9^{\circ}$ for $\mathbf{8}$, and $86.2^{\circ}$ and $89.7^{\circ}$ for 9 .

\section{Experimental}

\section{General remarks}

All manipulations were performed using standard glassware under aerobic conditions, except where otherwise noted. Solvents of analytical grade and deuterated solvents for NMR measurements were used as received. Literature methods were employed for the synthesis of $\mathbf{1}^{19}$ and $\mathrm{Ag}_{2} \mathrm{O} \cdot{ }^{26}$ All other reagents were used as received. Ether means diethyl ether and dmf dimethylformamide unless specified otherwise. NMR spectra were obtained on Bruker Avance AMX 250, 400, 500, 600 (QCI Quadruple Resonance CryoProbe) or Jeol Eclipse 300 spectrometers. The chemical shifts are given as dimensionless $\delta$ values and are frequency referenced relative to TMS for ${ }^{1} \mathrm{H}$ and ${ }^{13} \mathrm{C}$ and $\mathrm{Na}_{2} \mathrm{PtCl}_{6}$ for ${ }^{195} \mathrm{Pt}$. For ${ }^{1} \mathrm{H}-{ }^{15} \mathrm{~N}$ heteronuclear multiple-bond correlation (HMBC) experiments, $\mathrm{CH}_{3} \mathrm{NO}_{2}$ was used as the standard for the ${ }^{15} \mathrm{~N}$ chemical shifts $\left(\delta=381.7 v s\right.$. liquid $\left.\mathrm{NH}_{3}\right){ }^{27}$ In the HMBC experimental, $\mathrm{N}^{\mathrm{R}}$ stands for the alkyl substituted nitrogen of the imidazole ring and $\mathrm{N}^{\mathrm{O}}$ for the one next to the dioxolane ring.

Coupling constants $J$ are given in hertz $(\mathrm{Hz})$ as positive values regardless of their real individual signs. The multiplicity of the signals is indicated as $\mathrm{s}, \mathrm{d}$, or $\mathrm{m}$ for singlets, doublets, or multiplets, respectively. The abbreviation br is given for broadened signals. Mass spectra and high-resolution mass spectra were obtained in electrospray (ES) mode unless otherwise reported, on a Waters Q-Tof micromass spectrometer. IR spectra were measured on a JASCO 660plus FT-IR spectrometer from 4000 to $600 \mathrm{~cm}^{-1}$.

1,4:3,6-Dianhydro-2,5-dideoxy-2,5-bisimidazole-L-iditol, 3. 1 (9.1 g, $20.0 \mathrm{mmol})$ was dissolved in $\mathrm{dmf}(20 \mathrm{~mL})$. Imidazole $(2.9 \mathrm{~g}, 42.9 \mathrm{mmol})$ and caesium carbonate (16.3 g, $50.0 \mathrm{mmol})$ were added to the solution and the reaction temperature maintained at $100{ }^{\circ} \mathrm{C}$ for 1 day. A saturated brine solution $(150 \mathrm{~mL})$ was added to the reaction vessel and stirred until the yellow solid that formed had dissolved. The product was extracted with dichloromethane $(3 \times 50 \mathrm{~mL})$ and dried over $\mathrm{MgSO}_{4}$. The solution was filtered and solvent removed by reduced pressure to leave a white solid. The solid was washed with ether and dried. Yield: $3.9 \mathrm{~g}, 79 \%$. ${ }^{1} \mathrm{H}$ NMR (250 MHz, dmso-d $\left.{ }_{6}\right): 4.17$ (dd, $J=$ $10.5,2.4,1 \mathrm{H}$, endo- $\left.\mathrm{H}^{1 / 6}\right), 4.25\left(\mathrm{dd}, J=10.5,4.9,1 \mathrm{H}\right.$, exo $\left.-\mathrm{H}^{1 / 6}\right)$, $4.75\left(\mathrm{~s}, 1 \mathrm{H}, \mathrm{H}^{3 / 4}\right) 4.87\left(\mathrm{dd}, J=4.7,2.4 \mathrm{~Hz}, 1 \mathrm{H}, \mathrm{H}^{2 / 5}\right), 7.01(\mathrm{~d}$, $J=1.0,1 \mathrm{H}$, imid-H) 7.02 (d, $J=1.0,1 \mathrm{H}$, imid-H), 7.45 (s, 1H, $\left.\mathrm{C}_{\mathrm{NHC}} \mathrm{H}\right) .{ }^{13} \mathrm{C}$ NMR $\left(75 \mathrm{MHz}, \mathrm{CDCl}_{3}\right) \delta \mathrm{ppm} 63.00\left(\mathrm{C}^{2 / 5}\right), 72.75$ $\left(\mathrm{C}^{1 / 6}\right), 88.23\left(\mathrm{C}^{3 / 4}\right), 117.27$ (imid-C), 130.66 (imid-C), 135.95 $\left(\mathrm{C}_{\mathrm{NHC}}\right.$ ). ${ }^{15} \mathrm{~N} \mathrm{NMR}$ (from ${ }^{1} \mathrm{H}-{ }^{15} \mathrm{~N} \mathrm{HMBC}, 600 \mathrm{MHz}, \mathrm{CDCl}_{3}$ ) $\delta$ ppm $-122.5\left(\mathrm{~N}^{\mathrm{R}}\right), 191.2 \quad\left(\mathrm{~N}^{\mathrm{O}}\right)$. $\mathrm{MS}\left(\mathrm{AP}^{+}\right) \mathrm{m} / \mathrm{z} \quad(\%)$ : $\left[\mathrm{M}^{+}\right], \quad\left[\mathrm{C}_{12} \mathrm{H}_{15} \mathrm{~N}_{4} \mathrm{O}_{2}\right]^{+}$247.1195; measured: 247.1183 (100); $\left[\mathrm{MH}+\mathrm{CH}_{3} \mathrm{CN}^{+}\right], 288.1459$.

1,4:3,6-Dianhydro-2,5-dideoxy-2,5-bis(3-isopropyl imidazolium)-L-iditol iodide, 4I. The bis-imidazole 3 (1.4 g, $5.7 \mathrm{mmol})$ was dissolved in acetonitrile $(15 \mathrm{~mL})$, followed by the addition of isopropyliodide $(1.5 \mathrm{~mL}, 15.0 \mathrm{mmol})$. The mixture was refluxed for 1 day and subsequently left to cool to room temperature. The product crystallised out of the reaction solution and was subsequently filtered under suction and dried in air. Yield: $2.6 \mathrm{~g}, 69 \%$. ${ }^{1} \mathrm{H}$ NMR $\left(400 \mathrm{MHz}, \mathrm{D}_{2} \mathrm{O}\right): \delta$ ppm 1.44 
$(\mathrm{d}, 6 \mathrm{H}, J=6.7, \mathrm{CHMe}), 4.30\left(\mathrm{~m}, 2 \mathrm{H}, \mathrm{H}^{1 / 6}\right), 4.56(\mathrm{~m}, 1 \mathrm{H}$, $\left.\mathrm{CHMe}_{2}\right), 5.10\left(\mathrm{~s}, 1 \mathrm{H}, \mathrm{H}^{3 / 4}\right), 5.15\left(\mathrm{~m}, 1 \mathrm{H}, \mathrm{H}^{2 / 5}\right), 7.45$ (br s, $1 \mathrm{H}$, imid-H), 7.55 (br s, $1 \mathrm{H}$, imid-H), $8.86\left(\mathrm{~s}, 1 \mathrm{H}, \mathrm{C}_{\mathrm{NHC}} \mathrm{H}\right) .{ }^{13} \mathrm{C}$ NMR (125 MHz, D $\left.\mathrm{D}_{2} \mathrm{O}\right) \delta \mathrm{ppm} 22.2(\mathrm{CHMe}), 53.9\left(\mathrm{CHMe}_{2}\right)$, $65.0\left(\mathrm{C}^{2 / 5}\right), 72.1\left(\mathrm{C}^{1 / 6}\right), 87.3\left(\mathrm{C}^{3 / 4}\right), 121.3$ (imid-C), 121.7 (imidC), $134.0\left(\mathrm{C}_{\mathrm{NHC}}\right)$. MS $\left(\mathrm{ES}^{+}\right) \mathrm{m} / z$ : $[\mathrm{M}-\mathrm{I}]^{+},\left[\mathrm{C}_{18} \mathrm{H}_{27} \mathrm{~N}_{4} \mathrm{O}_{2}{ }^{127} \mathrm{I}\right]^{+}$: 459.1262; measured: 459.1262 (30); [MH - 2I] ${ }^{+}, 331.2138$ (40). Anal. Calcd for $\mathrm{C}_{18} \mathrm{H}_{28} \mathrm{I}_{2} \mathrm{~N}_{4} \mathrm{O}_{2}$ (586.25): C, 36.88; H, 4.81; N, 9.56. Found: C, 36.78; H, 4.79; N, 9.42.

1,4:3,6-Dianhydro-2,5-dideoxy-2,5-bis(3-isopropylimidazolium)L-iditol hexafluorophosphate $\left(\mathbf{4 P F}_{\mathbf{6}}\right)$. An aqueous solution of $\mathrm{KPF}_{6}(2.2 \mathrm{~g}, 12.0 \mathrm{mmol})$ was added slowly to a $20 \mathrm{~mL}$ aqueous solution of the bis-iodide salt 5I (1.9 g, $3.2 \mathrm{mmol})$. Immediately a white solid precipitated; it was collected by filtration. The solid was washed with cold ethanol and ether and left to dry under suction. Yield: $1.8 \mathrm{~g}, 91 \%$. ${ }^{1} \mathrm{H}$ NMR (250 MHz, dmso-d 6 ): $\delta=$ $1.50(\mathrm{~d}, J=6.7,6 \mathrm{H}, \mathrm{CHMe}), 4.33\left(\mathrm{~m}, 2 \mathrm{H}, \mathrm{CH}_{2}\right), 4.70(\mathrm{~m}, 1 \mathrm{H}$, $\mathrm{CHMe}$ ), 5.10 (s, 1H, CH), $5.25(\mathrm{~m}, 1 \mathrm{H}, \mathrm{CH}) 7.80$ (s, 1H, imid$\mathrm{H}), 8.05\left(\mathrm{~s}, 1 \mathrm{H}\right.$, imid-H), $9.25\left(\mathrm{~s}, 1 \mathrm{H}, \mathrm{C}_{\mathrm{NHC}} \mathrm{H}\right) ; \delta{ }^{13} \mathrm{C} \mathrm{NMR}$ $\left(100 \mathrm{MHz}, \mathrm{D}_{2} \mathrm{O}\right) \delta=22.29\left(\mathrm{CHCH}_{3}\right), 53.92\left(\mathrm{CHCH}_{3}\right), 65.05$ $\left(C^{2 / 5}\right), 72.13\left(C^{1 / 6}\right), 87.36\left(C^{3 / 4}\right), 121.34$ (imid-C), 121.75 (imidC), $133.99\left(\mathrm{C}_{\mathrm{NHC}}\right)$; IR (KBr) $844(\mathrm{~s}), 1097(\mathrm{~m}), 11601182$ (m), 1555 (m), 2906 (w), 3172 (sh, m), 3423 (br, w).

1,4:3,6-Dianhydro-2,5-dideoxy-2,5-bis(3-butyl imidazolium)-Liditol bromide (5Br). Bis-imidazole 3 (0.526 g, $2.14 \mathrm{mmol})$ was dissolved in dimethylformamide $(4 \mathrm{~mL})$, followed by addition of excess butylbromide $(4.2 \mathrm{~g}, 31.0 \mathrm{mmol})$. The mixture was heated to $100{ }^{\circ} \mathrm{C}$ for 2 days and subsequently left to cool to room temperature. Volatiles were evaporated and the residue was dissolved in hot $\mathrm{CH}_{3} \mathrm{CN}$. After storing for one day at $-5{ }^{\circ} \mathrm{C}$ colourless crystals of the product were obtained. Yield: $0.805 \mathrm{~g}$, $73 \%$. ${ }^{1} \mathrm{H}$ NMR $\left(250 \mathrm{MHz}, \mathrm{CDCl}_{3}\right) \delta \mathrm{ppm} 0.98$ (t, $J=7.3,3 \mathrm{H}$, $\left.\mathrm{CH}_{3}\right), 1.43\left(\mathrm{~m}, J=7.3,2 \mathrm{H}, \mathrm{CH}_{2}\right), 1.94\left(\mathrm{~m}, J=7.5,2 \mathrm{H}, \mathrm{CH}_{2}\right)$, $4.34\left(\mathrm{~m}, 3 \mathrm{H}, \mathrm{NCH}_{2} / \mathrm{H}^{1 / 6}\right), 4.54\left(\mathrm{dd}, J=4.50,1 \mathrm{H}, \mathrm{H}^{1 / 6}\right), 5.71(\mathrm{br}$ $\left.\mathrm{s}, 1 \mathrm{H}, \mathrm{H}^{2 / 5}\right), 5.77$ (br s, $\left.1 \mathrm{H}, \mathrm{H}^{3 / 4}\right), 7.46(\mathrm{~s}, 1 \mathrm{H}$, imid-H), $8.28(\mathrm{~s}$, imid-H, 1H), $10.22\left(\mathrm{~s}, 1 \mathrm{H}, \mathrm{C}_{\mathrm{NHC}} \mathrm{H}\right) .{ }^{13} \mathrm{C} \mathrm{NMR}(75 \mathrm{MHz}$, $\left.\mathrm{CD}_{3} \mathrm{Cl}\right): \delta=13.57\left(\mathrm{CH}_{3}\right), 19.64\left(\mathrm{CH}_{2}\right), 32.02\left(\mathrm{CH}_{2}\right), 50.20$ $\left(\mathrm{NCH}_{2}\right), 64.96\left(\mathrm{C}^{2 / 5}\right), 72.34\left(\mathrm{C}^{1 / 6}\right), 87.17\left(\mathrm{C}^{3 / 4}\right), 122.24(\mathrm{CH})$, $122.93(\mathrm{CH}), 136.8\left(\mathrm{C}_{\mathrm{NHC}}\right) .{ }^{15} \mathrm{~N} \mathrm{NMR}$ (from ${ }^{1} \mathrm{H}-{ }^{15} \mathrm{~N} \mathrm{HMBC}$, $\left.600 \mathrm{MHz}, \mathrm{CDCl}_{3}\right) \delta$ ppm $201.0\left(\mathrm{~N}^{\mathrm{O}}\right), 202.3\left(\mathrm{~N}^{\mathrm{R}}\right) . \mathrm{MS}\left(\mathrm{ES}^{+}\right)$ $m / z:[\mathrm{M}-\mathrm{Br}]^{+},\left[\mathrm{C}_{20} \mathrm{H}_{32} \mathrm{BrN}_{4} \mathrm{O}_{2}\right]^{+}: 439.17$ (30). Anal. Calcd for $\mathrm{C}_{20} \mathrm{H}_{32} \mathrm{Br}_{2} \mathrm{~N}_{4} \mathrm{O}_{2}$ (520.30): C, 46.17; H, 6.20; N, 10.77. Found: C, 46.07; H, 6.23; N, 10.66.

1,4:3,6-Dianhydro-2,5-dideoxy-2,5-bis(3-butylimidazolium)-Liditol hexafluorophosphate $\left(\mathbf{5 P F}_{\mathbf{6}}\right)$. An aqueous solution of $\mathrm{KPF}_{6}(2.2 \mathrm{~g}, 12.0 \mathrm{mmol})$ was added slowly to a $20 \mathrm{~mL}$ aqueous solution of the bis-bromide salt $\mathbf{5 B r}(0.527 \mathrm{~g}, 1.0 \mathrm{mmol})$. The product separated from the solution as a colourless oil. This was collected and dried to afford $0.353 \mathrm{~g}$ of the product. Yield: $0.353 \mathrm{~g}, 54 \%$. ${ }^{1} \mathrm{H}$ NMR (250 MHz, acetone- $\left.\mathrm{d}_{6}\right) \delta \mathrm{ppm} 0.96(\mathrm{t}$, $\left.J=7.5,3 \mathrm{H}, \mathrm{CH}_{3}\right) 1.39\left(\mathrm{~m}, 2 \mathrm{H}, \mathrm{CH}_{2}\right), 1.96(\mathrm{~m}, J=7.5,2 \mathrm{H}$, $\left.\mathrm{CH}_{2}\right), 4.40\left(\mathrm{t}, J=7.5,2 \mathrm{H}, \mathrm{NCH}_{2}\right), 4.52\left(\mathrm{~m}, J=2.2,2 \mathrm{H}, \mathrm{H}^{1 / 6}\right)$ $5.33\left(\mathrm{~s}, 1 \mathrm{H}, \mathrm{H}^{3 / 4}\right) 5.42\left(\mathrm{~m}, 1 \mathrm{H}, \mathrm{H}^{2 / 5}\right) 7.83(\mathrm{~m}, J=1.9,1 \mathrm{H}$, imid$\mathrm{H}), 7.90\left(\mathrm{~m}, 1 \mathrm{H}\right.$, imid-H), $9.20\left(\mathrm{~s}, 1 \mathrm{H}, \mathrm{C}_{\mathrm{NHC}} \mathrm{H}\right)$.

Preparation of $\left[\mathbf{A g}_{\mathbf{2}}(\boldsymbol{\mu}-\mathbf{4})_{2}\right] \mathbf{I}_{\mathbf{2}}$, 6I. 4I $(0.59 \mathrm{~g}, 1 \mathrm{mmol})$ was dissolved in a $1 / 1$ mixture of $\mathrm{CH}_{2} \mathrm{Cl}_{2}$ /acetone $(60 \mathrm{~mL})$. Silver(I) oxide $(0.25 \mathrm{~g}, 1.1 \mathrm{mmol})$ was subsequently added to the solution and the mixture was left stirring for 1 day. Then the solution was filtered through celite and dried. Yield: $0.814 \mathrm{~g}, 72 \% .{ }^{1} \mathrm{H}$ NMR (400 MHz, dmso-d 6 ): $\delta$ ppm 1.48 (d, $J=6.7,6 \mathrm{H}, \mathrm{CHMe}$ ), 1.49 $(\mathrm{d}, J=6.4,6 \mathrm{H}, \mathrm{CHMe} 2), 4.33\left(\mathrm{~m}, 4 \mathrm{H}, \mathrm{H}^{1 / 6}\right), 4.77(\mathrm{~m}, 2 \mathrm{H}$, $\left.\mathrm{CHMe}_{2}\right), 5.01\left(\mathrm{~s}, 2 \mathrm{H}, \mathrm{H}^{3 / 4}\right), 5.30\left(\mathrm{~m}, 2 \mathrm{H}, \mathrm{H}^{2 / 5}\right) 7.49(\mathrm{~m}, 2 \mathrm{H}$, imid-H), 7.67 (m, 2H, imid-H). ${ }^{13} \mathrm{C}$ NMR (75 MHz, dmso-d $\left.{ }_{6}\right)$ : $\delta$ ppm $23.85\left(\mathrm{CHMe}_{2}\right), 54.21\left(\mathrm{CHMe}_{2}\right), 66.73\left(\mathrm{C}^{2 / 5}\right), 72.72\left(\mathrm{C}^{1 / 6}\right)$, $88.51\left(\mathrm{C}^{3 / 4}\right), 119.53$ (imid-C), 120.76 (imid-C), 180.62 (s, $\left.\mathrm{C}_{\mathrm{NHC}}\right)$. MS $\left(\mathrm{ES}^{+}, \mathrm{CH}_{3} \mathrm{CN}\right): \mathrm{m} / z(\%)$, calcd mass for $[\mathrm{M}-\mathrm{I}]^{+}=$ $\left[\mathrm{C}_{36} \mathrm{H}_{52} \mathrm{~N}_{8} \mathrm{O}_{4}{ }^{107} \mathrm{Ag}_{2}{ }^{127} \mathrm{I}\right]^{+} 1001.1258$, measured: 1001.1306 (100).

Preparation of $\left[\mathrm{Ag}_{\mathbf{2}}(\boldsymbol{\mu}-\mathbf{4})_{2}\right]\left[\mathbf{P F}_{\mathbf{6}}\right]_{2} \cdot \mathbf{4 P F}_{\mathbf{6}}(0.310 \mathrm{~g}, 0.50 \mathrm{mmol})$ was dissolved in acetonitrile $(1 \mathrm{~mL})$. Silver(I) oxide $(0.115 \mathrm{~g}$, $0.5 \mathrm{mmol}$ ) was added to the solution along with sodium bromide $(0.27 \mathrm{~g}, 2.67 \mathrm{mmol})$ and the mixture heated to $100{ }^{\circ} \mathrm{C}$ for 1 day. The solvent was removed to leave a waxy light yellow solid. Yield: $0.443 \mathrm{~g}, 76 \%$. ${ }^{1} \mathrm{H}$ NMR (400 MHz, dmso-d 6 ): $\delta$ ppm 1.44 $(\mathrm{d}, J=6.7,6 \mathrm{H}, \mathrm{CHMe} 2), 1.45(\mathrm{~d}, J=6.4,6 \mathrm{H}, \mathrm{CHMe} 2), 4.32$ (dd, $J=10.5,5.3,2 \mathrm{H}$, endo- $\mathrm{H}^{1 / 6}$ ), 4.45 (br s, $J=10.5,2 \mathrm{H}$, exo$\left.\mathrm{H}^{1 / 6}\right), 4.72\left(\mathrm{~m}, 2 \mathrm{H}, \mathrm{CHMe}\right.$ ) $, 4.95\left(\mathrm{~s}, 2 \mathrm{H}, \mathrm{H}^{3 / 4}\right), 5.29$ (br s, 2H, $\left.\mathrm{H}^{2 / 5}\right) 7.50(\mathrm{~d}, J=1.8,2 \mathrm{H}$, imid-H), $7.70(\mathrm{~d}, J=1.8,2 \mathrm{H}$, imid$\mathrm{H})$; $\mathrm{MS}\left(\mathrm{ES}^{+}, \mathrm{CH}_{3} \mathrm{CN}\right): m / z(\%)$, calcd mass for $\left[\mathrm{M}-\mathrm{PF}_{6}\right]^{+}=$ $\left[\mathrm{C}_{36} \mathrm{H}_{52} \mathrm{~N}_{8} \mathrm{O}_{4} \mathrm{~F}_{6} \mathrm{P}^{107} \mathrm{Ag}_{2}\right]^{+} \quad 1019.1855$, measured 1019.1844 (100), 1033.1464 (15).

Preparation of $\left[\mathrm{Ag}_{2}(\boldsymbol{\mu}-5)_{2}\right] \mathbf{B r}_{2}, 7 \mathbf{B r}$. The imidazolium salt $\mathbf{5 B r}$ (0.390 g, $0.75 \mathrm{mmol}$ ) was dissolved in $30 \mathrm{~mL}$ of $\mathrm{CHCl}_{3}$, and $\mathrm{Ag}_{2} \mathrm{O}(0.174 \mathrm{~g}, 0.75 \mathrm{mmol})$ was added to the solution. After two hours the complex separated from the solution as an opaque oil. Volatiles were evaporated and the foam obtained was dissolved in $\mathrm{CHCl}_{3}$ with heating, filtered through celite and dried. Yield: $0.557 \mathrm{~g}, 68 \% .{ }^{1} \mathrm{H}$ NMR $\left(400 \mathrm{MHz}, \mathrm{CD}_{2} \mathrm{Cl}_{2}\right) \delta \mathrm{ppm} 0.86$ (t, $J=7.4,6 \mathrm{H}, \mathrm{Me}), 1.27\left(\mathrm{~m}, J=7.4,4 \mathrm{H}, \mathrm{CH}_{2}\right), 1.73(\mathrm{~m}, 4 \mathrm{H}$, $\left.\mathrm{CH}_{2}\right), 4.08\left(\mathrm{t}, J=7.2,4 \mathrm{H}, \mathrm{NCH}_{2}\right), 4.24(\mathrm{dd}, J=11.0,2.3,2 \mathrm{H}$, endo- $\left.\mathrm{H}^{1 / 6}\right), 4.34\left(\mathrm{dd}, J=11.0,5.0,2 \mathrm{H}\right.$, exo- $\left.\mathrm{H}^{1 / 6}\right), 4.97(\mathrm{~s}, 2 \mathrm{H}$, $\left.\mathrm{H}^{3 / 4}\right), 5.20\left(\mathrm{dd}, J=5.0,2.3,2 \mathrm{H}, \mathrm{H}^{2 / 5}\right), 7.02(\mathrm{~d}, J=2,2 \mathrm{H}$, imid$\mathrm{H}), 7.13\left(\mathrm{~d}, J=2,2 \mathrm{H}\right.$, imid-H). ${ }^{13} \mathrm{C} \mathrm{NMR}\left(75 \mathrm{MHz}, \mathrm{CD}_{2} \mathrm{Cl}_{2}\right): \delta$ ppm $13.52\left(\mathrm{CH}_{3}\right), 19.84\left(\mathrm{CH}_{2}\right), 33.46\left(\mathrm{CH}_{2}\right), 52.24\left(\mathrm{NCH}_{2}\right)$, $67.22\left(\mathrm{C}^{2 / 5}\right), 72.76\left(\mathrm{C}^{1 / 6}\right), 88.44\left(\mathrm{C}^{3 / 4}\right), 119.42$ (imid-C), 121.90 (imid-C), 181.26 (s, $\mathrm{C}_{\mathrm{NHC}}$ ). ${ }^{15} \mathrm{~N} \mathrm{NMR}$ (from ${ }^{1} \mathrm{H}-{ }^{15} \mathrm{~N} \mathrm{HMBC}$, $\left.600 \mathrm{MHz}, \mathrm{CD}_{2} \mathrm{Cl}_{2}\right) \delta$ ppm $211.3\left(\mathrm{~N}^{\mathrm{R}}\right), 212.5\left(\mathrm{~N}^{\mathrm{O}}\right) . \mathrm{MS}\left(\mathrm{ES}^{+}\right)$ $m / z:[\mathrm{M}-\mathrm{Br}]^{+},\left[\mathrm{C}_{40} \mathrm{H}_{60}{ }^{107} \mathrm{Ag}_{2}{ }^{79} \mathrm{BrN}_{8} \mathrm{O}_{4}\right]^{+}:$1009.2023; measured: 1009.1985 (30).

For the ${ }^{1} \mathrm{H}$ and ${ }^{13} \mathrm{C}$ NMR spectra of the platinum complexes, 8-10 reported below, signals for all 3 observed isomers are reported with individual peaks not assigned to a specific isomer.

Preparation of cis- $\left[\mathbf{P t}_{\mathbf{2}}(\boldsymbol{\mu}-\mathbf{2})\left(\mathbf{d m s o}_{\mathbf{2}} \mathbf{C l}_{\mathbf{4}}\right]\right.$, 8. 2PF $\mathbf{P F}_{\mathbf{6}}(0.187 \mathrm{~g}$, $0.33 \mathrm{mmol}), \mathrm{K}_{2} \mathrm{PtCl}_{4}(0.278 \mathrm{~g}, 0.67 \mathrm{mmol})$ and $\mathrm{NaOAc}$ $(0.057 \mathrm{~g}, 0.70 \mathrm{mmol})$ were dissolved in $1 \mathrm{~mL}$ of dmso at $70{ }^{\circ} \mathrm{C}$. The reaction mixture was stirred at that temperature for 3 days. The solution was dried under vacuum and the yellowish solid obtained was washed three times with methanol and subsequently dried. The white solid obtained was recrystallised by diffusion of hexane into a dichloromethane solution to afford block colourless plates of the product. Yield: $0.300 \mathrm{~g}(94 \%)$. ${ }^{1} \mathrm{H}$ NMR (400 MHz, $\mathrm{CD}_{3} \mathrm{CN}$ ) $\delta$ ppm 3.44/3.45/3.47/3.51/3.52/3.53 (s, 12H, $\mathrm{Me}_{2} \mathrm{SO}$ ), 3.96/3.97/3.97/3.98 (s, 6H, Me), 4.14 (dd, 
$J=3.8,7.2) / 4.17(\mathrm{dd}, J=3.2,7.2) / 4.20(\mathrm{~m}) / 4.23(\mathrm{~m}, 2 \mathrm{H}$, endo$\left.\mathrm{H}^{1 / 6}\right), 4.50\left(\mathrm{~m}, 2 \mathrm{H}\right.$, exo- $\left.\mathrm{H}^{1 / 6}\right), 5.05$ (br s, $\left.2 \mathrm{H}, \mathrm{H}^{3 / 4}\right), 5.92 / 6.06$ $\left(\mathrm{m}, 2 \mathrm{H}, \mathrm{H}^{2 / 5}\right), 7.08(\mathrm{~d}, J=2.3) / 7.09(\mathrm{~d}, J=2.3) / 7.12(\mathrm{~d}, J=$ 2.1)/7.13 (d, $J=2.3,2 \mathrm{H}$, imid-H), 7.18 (br s, $2 \mathrm{H}$, imid-H). ${ }^{13} \mathrm{C}$ NMR $\left(125 \mathrm{MHz}, \mathrm{dmso}_{\mathrm{d}}\right) \delta \mathrm{ppm} 37.61 / 37.64 / 37.71\left(\mathrm{CH}_{3}\right)$, 65.80/65.90/66.05/66.11 $\left(C^{2 / 5}\right), 72.04 / 72.08 / 72.11 / 72.17\left(C^{1 / 6}\right)$, 87.48/87.56/87.75/87. $48\left(C^{3 / 4}\right), 118.54 / 118.69 / 118.82$ (imid- $C$ ), $124.74 / 124.79$ (imid- $C$ ), $143.60 \quad\left(\mathrm{C}_{\mathrm{NHC}}\right) .{ }^{15} \mathrm{~N} \mathrm{NMR}$ (from ${ }^{1} \mathrm{H}-{ }^{15} \mathrm{~N}$ HMBC, $600 \mathrm{MHz}$, dmso-d 6 ) $\delta$ ppm $192.4\left(\mathrm{~N}^{\mathrm{R}}\right), 193.1$ $\left(\mathrm{N}^{\mathrm{R}}\right), 203.2\left(\mathrm{~N}^{\mathrm{O}}\right), 205.3\left(\mathrm{~N}^{\mathrm{O}}\right) .{ }^{195} \mathrm{Pt}$ NMR (107 MHz, dmso-d 6 ) $\delta$ ppm -3525, -3533. IR ( $\left.\mathrm{KBr}, v_{\max } / \mathrm{cm}^{-1}\right) 1022(\mathrm{~s}), 1092$ and 1134 (s, SO). UV ( $\left.\mathrm{CH}_{3} \mathrm{CN}, 0.14 \mathrm{mM}\right) 254 \mathrm{~nm}$ (intense $\mathrm{dm}^{3}$ $\mathrm{mol}^{-1} \mathrm{~cm}^{-1}$ ), $300 \mathrm{~nm}$ (faint shoulder $1214 \mathrm{dm}^{3} \mathrm{~mol}^{-1} \mathrm{~cm}^{-1}$ ). MS (accurate mass, $\left.\mathrm{ES}^{+}, \mathrm{CH}_{3} \mathrm{CN}\right) \mathrm{m} / z(\%)$, calculated mass for $[\mathrm{M}+\mathrm{K}]^{+},\left[\mathrm{C}_{18} \mathrm{H}_{30} \mathrm{Cl}_{4} \mathrm{KN}_{4} \mathrm{O}_{4} \mathrm{Pt}_{2} \mathrm{~S}_{2}\right]^{+}:$1000.9360; measured: 1000.9361. Anal. Calcd for $\mathrm{C}_{18} \mathrm{H}_{30} \mathrm{Cl}_{4} \mathrm{~N}_{4} \mathrm{O}_{4} \mathrm{Pt}_{2} \mathrm{~S}_{2}$ (962.55): C, 22.46; H, 3.14; N, 5.82. Found: C, 22.44; H, 3.13; N, 5.90.

Preparation of cis- $\left[\mathrm{Pt}_{\mathbf{2}}(\boldsymbol{\mu - 4})(\mathbf{d m s o})_{2} \mathbf{C l}_{4}\right]$, 9. In a round bottom flask, $\mathrm{K}_{2} \mathrm{PtCl}_{4}(0.278 \mathrm{~g}, 0.67 \mathrm{mmol})$ and $\mathbf{4} \mathbf{P F}_{\mathbf{6}}(0.208 \mathrm{~g}$, $0.33 \mathrm{mmol})$ were dissolved in $2 \mathrm{~mL}$ of dmso. NaOAc $(0.057 \mathrm{~g}$, $0.70 \mathrm{mmol}$ ) was subsequently added, and the mixture heated to $70{ }^{\circ} \mathrm{C}$ for 1 day. The solution was dried in a Kügelrohr under vacuum and the yellowish solid obtained was extracted with $\mathrm{CH}_{3} \mathrm{CN}$. The $\mathrm{CH}_{3} \mathrm{CN}$ washings were condensed to $c a .2 \mathrm{~mL}$ volume and methanol was added to precipitate the complex as a white solid. Complex 9 was recrystallised by storing a saturated $\mathrm{CH}_{3} \mathrm{CN} /$ methanol solution of 9 at $-5{ }^{\circ} \mathrm{C}$. ${ }^{1} \mathrm{H} \mathrm{NMR}(400 \mathrm{MHz}$, $\left.\mathrm{CD}_{2} \mathrm{Cl}_{2}\right) \delta \mathrm{ppm} 1.40(\mathrm{~m}, 12 \mathrm{H}, \mathrm{CHMe}$ ), 3.38/3.42/3.53/3.54 (s, $\left.12 \mathrm{H}, \mathrm{Me}_{2} \mathrm{SO}\right), 4.23\left(\mathrm{dd}, J=11.4,1.9,2 \mathrm{H}\right.$, endo $\left.-\mathrm{H}^{1 / 6}\right), 4.31$ $(\mathrm{dd}, J=11.4,4.8) / 4.37\left(\mathrm{dd}, J=11.1,5.6,2 \mathrm{H}\right.$, exo- $\left.\mathrm{H}^{1 / 6}\right), 4.89$ $\left(\mathrm{d},{ }^{3} J=5\right) / 4.93(\mathrm{~s}) / 5.01(\mathrm{~s}) / 5.07\left(\mathrm{~d},{ }^{3} J=5,2 \mathrm{H}, \mathrm{H}^{3 / 4}\right), 5.56(\mathrm{~m}$, $\left.2 \mathrm{H}, \mathrm{CH} \mathrm{Me}_{2}\right), 5.81 / 6.16\left(\mathrm{~m}, 2 \mathrm{H}, \mathrm{H}^{2 / 5}\right), 6.89 / 6.90 / 6.95 / 6.97 /$ 6.98-7.00 (m)/7.03 (d, ${ }^{3} J=2.2,4 \mathrm{H}$, imid-H). ${ }^{13} \mathrm{C}$ NMR (125 MHz, CD $\left.{ }_{3} \mathrm{CN}\right) \delta$ ppm 20.78/20.80/20.93/20.95 ( $\left.\mathrm{CHMe}_{2}\right)$, 44.52/44.59/44.66/44.71 ( $\left.\mathrm{Me}_{2} \mathrm{SO}\right), \quad 52.77 / 52.82 \quad\left(\mathrm{CHMe}_{2}\right)$, 65.63/65.74/65.93/66.03 $\left(\mathrm{C}^{2 / 5}\right), 71.26 / 71.35 / 71.45 / 71.62\left(\mathrm{C}^{1 / 6}\right)$, $86.87 / 86.94 / 87.11 / 87.26 \quad\left(\mathrm{C}^{3 / 4}\right), \quad 118.11 / 118.17 / 118.25 / 118.60$ (imid-C), $118.57 / 118.60$ (imid-C), $142.43 / 142.16\left(\mathrm{C}_{\mathrm{NHC}}\right) .{ }^{15} \mathrm{~N}$ NMR (from ${ }^{1} \mathrm{H}-{ }^{15} \mathrm{~N} \mathrm{HMBC}, 600 \mathrm{MHz}, \mathrm{CD}_{3} \mathrm{CN}$ ) $\delta$ ppm 202.1 $\left(\mathrm{N}^{\mathrm{O}}\right), 218.1\left(\mathrm{~N}^{\mathrm{R}}\right) .{ }^{195} \mathrm{Pt} \mathrm{NMR}\left(107 \mathrm{MHz}, \mathrm{CH}_{3} \mathrm{CN}-\mathrm{d}_{3}\right) \delta \mathrm{ppm}$ $-3514,-3521$. IR (KBr, $\left.v_{\max } / \mathrm{cm}^{-1}\right) 1022(\mathrm{~m}), 1096$ and 1144 (s, SO). MS (ES $\left.{ }^{+} \mathrm{CH}_{3} \mathrm{CN}\right): m / z(\%)$, calcd mass for $[\mathrm{M}+\mathrm{K}]^{+}=\left[\mathrm{C}_{22} \mathrm{H}_{38} \mathrm{Cl}_{4} \mathrm{KN}_{4} \mathrm{O}_{4} \mathrm{Pt}_{2} \mathrm{~S}_{2}\right]^{+}$1055.9971, measured 1055.9971 (22), 1000.09 (45). Anal. Calcd for $\mathrm{C}_{22} \mathrm{H}_{38} \mathrm{Cl}_{4}$ $\mathrm{N}_{4} \mathrm{O}_{4} \mathrm{Pt}_{2} \mathrm{~S}_{2}$ (1018.66): C, 25.94; H, 3.76; N, 5.50. Found: C, 25. 89 ; H, 3.81; N, 5.30 .

Preparation of cis- $\left[\mathrm{Pt}_{\mathbf{2}}(\boldsymbol{\mu - 5})(\mathbf{d m s o})_{2} \mathbf{C l}_{\mathbf{4}}\right], \mathbf{1 0}$. In a round bottom flask, $\mathrm{PtCl}_{2}(0.291 \mathrm{~g}, 1.1 \mathrm{mmol})$ and $\mathbf{5} \mathbf{P F}_{\mathbf{6}}(0.353 \mathrm{~g}, 0.54 \mathrm{mmol})$ were dissolved in $4 \mathrm{~mL}$ of dmso. NaOAc $(0.097 \mathrm{~g}, 1.2 \mathrm{mmol})$ was subsequently added, and the mixture heated to $65{ }^{\circ} \mathrm{C}$ for 2.5 days. The pale yellow solution was dried under vacuum and the yellowish oil obtained was extracted with $\mathrm{CHCl}_{3}(2 \times$ $20 \mathrm{~mL}$ ). The $\mathrm{CHCl}_{3}$ washings were condensed to afford a colourless oil. Yield: $0.522 \mathrm{~g}, 93 \% .{ }^{1} \mathrm{H}$ NMR (400 MHz, acetone$\mathrm{d}_{6} / \mathrm{dmso}^{\left.-\mathrm{d}_{6}\right)} \delta$ ppm $0.97(\mathrm{t}, J=7.5,6 \mathrm{H}, \mathrm{Me}), 1.43\left(\mathrm{~m},{ }^{3} J=7.5\right.$, $\left.4 \mathrm{H}, \mathrm{CH}_{2}\right), 1.99\left(\mathrm{~m}, 4 \mathrm{H}, 2 \times \mathrm{CH}_{2}\right), 3.60\left(\mathrm{~m}, 12 \mathrm{H}, \mathrm{Me}_{2} \mathrm{SO}\right), 4.12$ (dd, $J=10.5,4.2) / 4.21\left(\mathrm{~m}, J=10.7,3.4,2 \mathrm{H}\right.$, endo- $\left.\mathrm{H}^{1 / 6}\right), 4.44$ $\left(\mathrm{m}, 1 \mathrm{H}+4 \mathrm{H}, \mathrm{CH}_{2}\right.$, exo- $\left.\mathrm{H}^{1 / 6}\right), 4.63(\mathrm{dd}, J=10.7,5.1) / 4.64(\mathrm{dd}$, $J=10.5,4.2,1 \mathrm{H}$, exo- $\left.\mathrm{H}^{1 / 6}\right), 5.15\left(\mathrm{~m}, 2 \mathrm{H}, \mathrm{H}^{3 / 4}\right), 6.02 / 6.12(\mathrm{~m}$, $\left.2 \mathrm{H}, \mathrm{H}^{2 / 5}\right), 7.26(\mathrm{~d}, J=2.1) / 7.29(\mathrm{~d}, J=2.1) / 7.38(\mathrm{~d}, J=2.1) /$ 7.42 (d, $J$ 2.1, 2H, imid-H), 7.51 (br s, 2H, imid-H). ${ }^{13} \mathrm{C} \mathrm{NMR}$ (75 MHz, acetone- $\mathrm{d}_{6} / \mathrm{dmso}^{\left.-\mathrm{d}_{6}\right)} \delta \mathrm{ppm} 13.50\left(\mathrm{CH}_{3}\right), 19.67$ $\left(\mathrm{CH}_{3} \mathrm{CH}_{2}\right), 32.03\left(\mathrm{CH}_{2}\right), \quad 50.41 \quad\left(\mathrm{NCH}_{2}\right), 66.20 / 66.44 / 66.69$ $\left(\mathrm{C}^{2 / 5}\right), \quad 72.17 / 72.23 / 72.41 \quad\left(\mathrm{C}^{1 / 6}\right), \quad 87.68 / 87.77 / 87.92 \quad\left(\mathrm{C}^{3 / 4}\right)$, $118.49 / 118.80 \quad$ (imid-C), 122.92/123.14/123.19 (imid-C), 144.15/144.31 ( $\mathrm{C}_{\mathrm{NHC}}$ ). ${ }^{15} \mathrm{~N}$ NMR (from ${ }^{1} \mathrm{H}-{ }^{15} \mathrm{~N} \mathrm{HMBC}$, $600 \mathrm{MHz}, \mathrm{CD}_{2} \mathrm{Cl}_{2}$ ) $\delta$ ppm 204.5 (br s). ${ }^{195} \mathrm{Pt}$ NMR $(107 \mathrm{MHz}$, $\left.\mathrm{CH}_{2} \mathrm{Cl}_{2}-\mathrm{d}_{2}\right) \delta \mathrm{ppm}-3518,-3521$. MS $\left(\mathrm{ES}^{+}\right) \mathrm{m} / \mathrm{z}$ : $[\mathrm{M}+\mathrm{Na}]^{+}$, $\left[\mathrm{C}_{24}-\mathrm{H}_{42}{ }^{35} \mathrm{Cl}_{4}{ }^{23} \mathrm{NaN}_{4} \mathrm{O}_{4}{ }^{194} \mathrm{Pt}_{2}{ }^{32} \mathrm{~S}_{2}\right]^{+}$: 1065.0553 ; measured: 1065.0503 (20). Anal. Calcd for $\mathrm{C}_{24} \mathrm{H}_{42} \mathrm{Cl}_{4} \mathrm{~N}_{4} \mathrm{O}_{4} \mathrm{Pt}_{2} \mathrm{~S}_{2}$ (1046.71): C, 27.54; H, 4.04; N, 5.35. Found: C, 27.48; H, 3.97; N, 5.49 .

\section{X-ray crystallography}

Data for 4I were measured at $120 \mathrm{~K}$ on a Bruker Nonius KappaCCD diffractometer at the window of a Bruker Nonius FR591 rotating anode $\left(\lambda_{\mathrm{Mo}-\mathrm{K} \alpha}=0.71073 \AA\right)$ driven by COLLECT and processed by DENZO software. ${ }^{28}$ The structure was determined in SHELXS-97 and refined using SHELXL-97. ${ }^{29}$ Data for $\mathbf{8}$ and $\mathbf{9}$ were obtained from very small and weakly diffracting crystals by use of synchrotron radiation $(\lambda=0.6889 \AA)$ at $120 \mathrm{~K}$, with a Crystal Logics kappa diffractometer and Rigaku Saturn 724+ CCD detector at beamline I19 of Diamond Light Source; software was Rigaku CrystalClear, ${ }^{30}$ and Bruker $\mathrm{APEX}^{31}$ and SHELXTL. ${ }^{29}$ Key crystallographic data are shown in Table 1.

In addition to the intended compound 9 (with 8 identical molecules in the tetragonal unit cell, all of the same chirality), the structure also contains highly disordered solvent and/or other components that could not be modelled as discrete atoms and could not be identified from the observed electron density distribution. This has been treated with the SQUEEZE option of the program PLATON. ${ }^{32}$ The refined structural model contains only the ordered part of the crystal structure and the unidentified disordered components are not included in any of the tabulated or deposited values. The crystal structure of $\mathbf{8}$ contains disordered dichloromethane solvent molecules, which it was possible to model with discrete atom positions. For all three structures, the correct enantiomer was confirmed on the basis of significant anomalous scattering effects. ${ }^{33}$

Crystallographic data for all compounds have been deposited with the Cambridge Crystallographic Data Centre as supplementary publications CCDC 893546-893548.

\section{Conclusions}

Short synthetic routes to the chiral, ether-functionalized NHC precursors, 20Ts, 4I and $\mathbf{5 B r}$ have been developed. The bridging ligands 2, 4 and 5 form either cationic dinuclear cyclic structures with $\mathrm{Ag}(\mathrm{I})$ or neutral linear complexes in the case of $\mathrm{Pt}(\mathrm{II})$. The robust nature of the $\mathrm{Pt}(\mathrm{II})$ complexes is indicated by their synthesis being achieved under aerobic conditions using bench grade solvents. For the cis- $\mathrm{Pt}(\mathrm{dmso}) \mathrm{Cl}_{2}$ complexes, 
Table 1 Crystallographic data for $\mathbf{4 I}, 8$ and 9

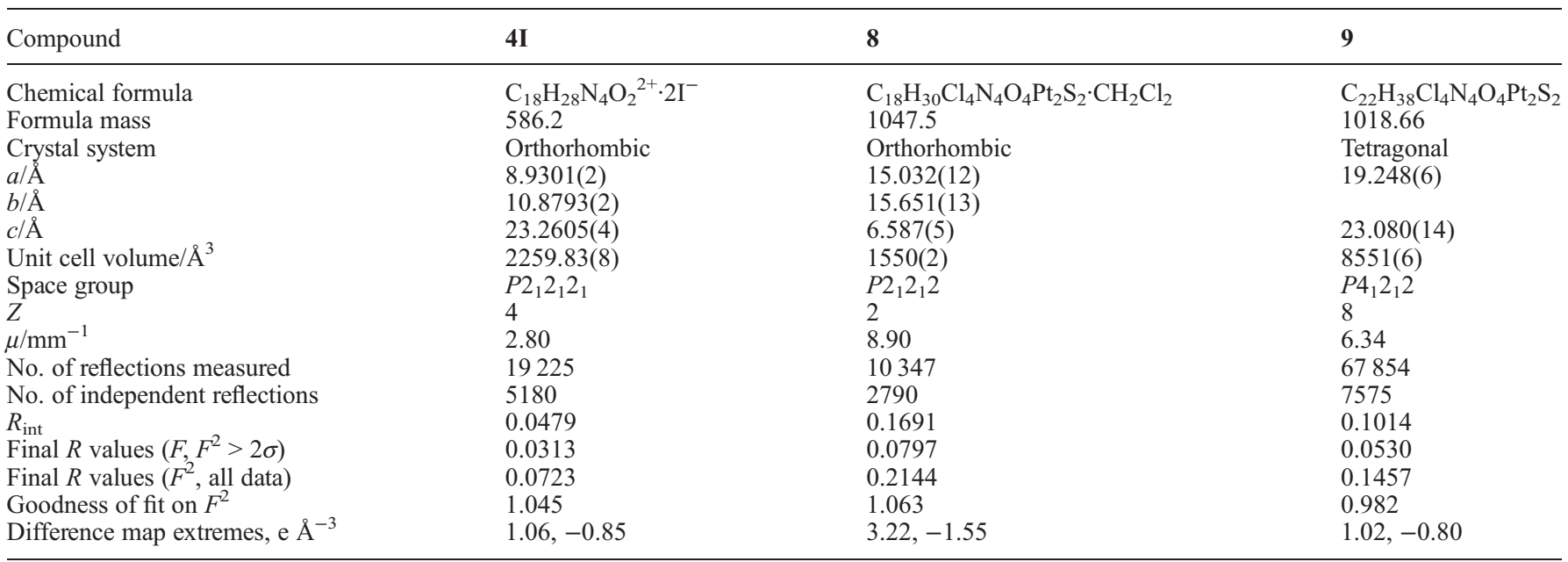

hindered rotation of the carbene ligand about the metal-NHC bond is evident in their ${ }^{1} \mathrm{H},{ }^{13} \mathrm{C},{ }^{15} \mathrm{~N}$ and ${ }^{195} \mathrm{Pt}$ NMR spectra, where more than one rotamers can be observed.

\section{Acknowledgements}

We thank the EPSRC for funding for the National Crystallography Service (Southampton and Newcastle Universities), and Diamond Light Source for access to beamline I19.

\section{Notes and references}

1 (a) C. X. Lu, S. J. Gu, W. Z. Chen and H. Y. Qiu, Dalton Trans., 2010, 39, 4198-4204; (b) D. Troegel and J. Stohrer, Coord. Chem. Rev., 2011, 255, 1440-1459; (c) I. E. Marko, S. Sterin, O. Buisine, G. Mignani, P. Branlard, B. Tinant and J. P. Declercq, Science, 2002, 298, 204-206; (d) G. F. Silbestri, J. C. Flores and E. de Jesus, Organometallics, 2012, 31, 3355-3360; (e) J. J. Hu, F. W. Li and T. S. A. Hor, Organometallics, 2009, 28, 1212-1220.

2 R. Zhang, Q. Xu, L. Y. Mei, S. K. Li and M. Shi, Tetrahedron, 2012, 68, 3172-3178.

3 V. Lillo, J. A. Mata, A. M. Segarra, E. Peris and E. Fernandez, Chem. Commun., 2007, 2184-2186.

4 V. Lillo, J. Mata, J. Ramirez, E. Peris and E. Fernandez, Organometallics, 2006, 25, 5829-5831.

5 S. Das Adhikary, D. Bose, P. Mitra, K. Das Saha, V. Bertolasi and J. Dinda, New J. Chem., 2012, 36, 759-767.

6 Y. Unger, A. Zeller, M. A. Taige and T. Strassner, Dalton Trans., 2009, 4786-4794.

7 S. Fantasia, J. L. Petersen, H. Jacobsen, L. Cavallo and S. P. Nolan, Organometallics, 2007, 26, 5880-5889.

8 (a) C. P. Newman, R. J. Deeth, G. J. Clarkson and J. P. Rourke, Organometallics, 2007, 26, 6225-6233; (b) D. Meyer, A. Zeller and T. Strassner, J. Organomet. Chem., 2012, 701, 56-61.

9 (a) A. J. Arduengo, H. V. R. Dias, J. C. Calabrese and F. Davidson, Organometallics, 1993, 12, 3405-3409; (b) O. Guerret, S. Sole, H. Gornitzka, M. Teichert, G. Trinquier and G. Bertrand, J. Am. Chem. Soc., 1997, 119, 6668-6669; (c) H. M. J. Wang and I. J. B. Lin, Organometallics, 1998, 17, 972-975; (d) M. Boronat, A. Corma, C. Gonzalez-Arellano, M. Iglesias and F. Sanchez, Organometallics, 2010, 29, 134-141; (e) H. V. Huynh, C. H. Yeo and Y. X. Chew, Organometallics, 2010, 29, 1479-1486.

10 (a) Y. L. Li, K. Hindi, K. M. Watts, J. B. Taylor, K. Zhang, Z. C. Li, D. A. Hunstad, C. L. Cannon, W. J. Youngs and K. L. Wooley, Chem. Commun., 2010, 46, 121-123; (b) S. Patil, J. Claffey, A. Deally, M. Hogan, B. Gleeson, L. M. M. Mendez, H. Muller-Bunz, F. Paradisi and M. Tacke, Eur. J. Inorg. Chem., 2010, 1020-1031; (c) A. KascatanNebioglu, M. J. Panzner, C. A. Tessier, C. L. Cannon and W. J. Youngs, Coord. Chem. Rev., 2007, 251, 884-895; (d) A. Melaiye, R. S. Simons, A. Milsted, F. Pingitore, C. Wesdemiotis, C. A. Tessier and W. J. Youngs, J. Med. Chem., 2004, 47, 973-977; (e) A. Kascatan-Nebioglu, A. Melaiye, K. Hindi, S. Durmus, M. J. Panzner, L. A. Hogue, R. J. Mallett, C. E. Hovis, M. Coughenour, S. D. Crosby, A. Milsted, D. L. Ely, C. A. Tessier, C. L. Cannon and W. J. Youngs, J. Med. Chem., 2006, 49, 6811-6818; (f) J. C. Garrison and W. J. Youngs, Chem. Rev, $2005, \mathbf{1 0 5}, 3978-4008$.

11 J. C. Y. Lin, R. T. W. Huang, C. S. Lee, A. Bhattacharyya, W. S. Hwang and I. J. B. Lin, Chem. Rev., 2009, 109, 3561-3598.

12 L. Ray, M. M. Shaikh and P. Ghosh, Inorg. Chem., 2007, 47, 230-240.

13 V. J. Catalano, M. A. Malwitz and A. O. Etogo, Inorg. Chem., 2004, 43, 5714-5724.

14 A. B. Powell, C. W. Bielawski and A. H. Cowley, J. Am. Chem. Soc., 2009, 131, 18232-18233.

15 V. J. Catalano and M. A. Malwitz, Inorg. Chem., 2003, 42, 5483-5485.

16 A. Rit, T. Pape and F. E. Hahn, J. Am. Chem. Soc., 2010, 132, $4572-4573$.

17 B. Liu, W. Z. Chen and S. W. Jin, Organometallics, 2007, 26, 3660-3667.

18 (a) C. Carcedo, A. Dervisi, I. A. Fallis, L. Ooi and K. M. A. Malik, Chem. Commun., 2004, 1236-1237; (b) A. Dervisi, C. Carcedo and L.-1. Ooi, Adv. Synth. Catal., 2006, 348, 175-183.

19 C. Carcedo, J. C. Knight, S. J. A. Pope, I. A. Fallis and A. Dervisi, Organometallics, 2011, 30, 2553-2562.

20 G. L. Petretto, M. A. Wang, A. Zucca and J. P. Rourke, Dalton Trans., 2010, 39, 7822-7825.

21 (a) S. Burling, S. Douglas, M. F. Mahon, D. Nama, P. S. Pregosin and M. K. Whittlesey, Organometallics, 2006, 25, 2642-2648; (b) A. R. Chianese, X. W. Li, M. C. Janzen, J. W. Faller and R. H. Crabtree, Organometallics, 2003, 22, 1663-1667; (c) M. Iglesias, D. J. Beetstra, A. Stasch, P. N. Horton, M. B. Hursthouse, S. J. Coles, K. J. Cavell, A. Dervisi and I. A. Fallis, Organometallics, 2007, 26, 4800-4809; (d) L. Busetto, M. C. Cassani, C. Femoni, M. Mancinelli, A. Mazzanti, R. Mazzoni and G. Solinas, Organometallics, 2011, 30, $5258-5272$.

22 B. M. Still, P. G. A. Kumar, J. R. Aldrich-Wright and W. S. Price, Chem. Soc. Rev., 2007, 36, 665-686.

23 (a) T. Pawlak, L. Pazderski, J. Sitkowski, L. Kozerski and E. Szlyk, Magn. Reson. Chem., 2011, 49, 59-64; (b) L. Pazderski, T. Pawlak, J. Sitkowski, L. Kozerski and E. Szlyk, Magn. Reson. Chem., 2010, 48 , 417-426; (c) L. Pazderski, T. Pawlak, J. Sitkowski, L. Kozerski and E. Szlyk, Magn. Reson. Chem., 2009, 47, 932-941; (d) L. Pazderski, J. Tousek, J. Sitkowski, L. Kozerski and E. Szlyk, Magn. Reson. Chem., 2009, 47, 658-665; (e) L. Pazderski, E. Szlyk, J. Sitkowski, B. Kamienski, L. Kozerski, J. Tousek and R. Marek, Magn. Reson. Chem., 2006, 44, 163-170. 
24 L. Pazderski, E. Szłyk, J. Sitkowski, B. Kamieński, L. Kozerski, J. Toušek and R. Marek, Magn. Reson. Chem., 2006, 44, 163-170.

25 D. Brissy, M. Skander, P. Retailleau and A. Marinetti, Organometallics, 2007, 26, 5782-5785.

26 (a) C. V. W. Donald and E. Janssen, Org. Synth., 1963, Coll. Vol. 4, 547; (b) C. V. W. Donald and E. Janssen, Org. Synth., 1956, 36, 46.

27 E. Procházková, M. Šála, R. Nencka and M. Dračínský, Magn. Reson. Chem., 2012, 50, 181-186.
28 Z. M. W. Otwinowski, Methods in Enzymology, Academic Press, New York, 1997.

29 M. Sheldrick, Acta Crystallogr., Sect. A: Found. Crystallogr., 2008, 64, 112.

30 R. C. CrystalClear Software for Data Collection, The Woodlands, TX, 2008. 31 B. A. I. APEX2 Software for Data Processing, Madison, WI, 2008.

32 A. L. Spek, J. Appl. Crystallogr., 2003, 36, 7.

33 H. D. Flack, Acta Crystallogr., Sect. A: Found. Crystallogr., 1983, 39, 876. 